\title{
PENGARUH PEMBERIAN RANSUM KOMERSIL DENGAN PENAMBAHAN BAHAN PAKAN LOKAL TERFERMENTASI AMONIUM SULFAT DAN UREA TERHADAP BOBOT HIDUP, BOBOT KARKAS, DAN BOBOT GIBLET ITIK HIBRIDA JANTAN
}

\section{The Influence of giving Commercial Ration with Addition of Local Feed fermented with Ammonium Sulphate and Urea on Live Weight, Carcass Weight, and Giblet Weight of Male Hybrid Duck}

\author{
Amir Husein, Rudy Sutrisna, dan Dian Septinova \\ Department of Animal Husbandry, Faculty of Agriculture Lampung University \\ Soemantri Brojonegoro No. 1 Gedong Meneng Bandar Lampung 35145 \\ e-mail : amirhusein268@gmail.com
}

\begin{abstract}
This research aimed to know the influence of giving a commercial ration with addition of local feed fermented with ammonium sulphate and urea and to find out the best ration on live weight, carcass weight, and giblet weight of male hybrid ducks. This research was carried out in July 2018--August 2018 in the cage of ducks, Department of Animal Husbandry, Faculty of Agriculture, Lampung University. Research material used consisted of 40 male hybrid ducks. This study used a Completely Randomized Design (CRD). Data was analysed using analysis of variance at $5 \%$ level of significance. The results showed that there was no different effect of treatments on live weight (1,552--1,717 g / duck), carcass weight (805,6--1.016 g / duck), and giblet weight (106.8--118.45 g/duck) of male hybrid ducks.
\end{abstract}

Keywords: Carcass weight, Giblet weight, Live weight, Male hybrid duck.

\begin{abstract}
ABSTRAK
Penelitian ini bertujuan untuk mengetahui pengaruh pemberian ransum komersil dengan penambahan bahan pakan lokal terfermentasi amonium sulfat dan urea serta untuk mengetahui pemberian ransum terbaik terhadap bobot hidup, bobot karkas, dan giblet pada itik hibrida jantan. Penelitian ini dilaksanakan pada Juli 2018--Agustus 2018 di kandang Itik, Jurusan Peternakan, Fakultas Pertanian, Universitas Lampung. Materi penelitian yang digunakan terdiri dari 40 ekor itik hibrida jantan, ransum perlakuan, bobot hidup, bobot karkas, dan giblet. Penelitian ini menggunakan metode Rancangan Acak Lengkap (RAL). Analisis data dilakukan dengan analisis of varian (ANOVA) pada taraf nyata $5 \%$ terhadap bobot hidup, bobot karkas, dan giblet. Berdasarkan hasil penelitian pemberian ransum dengan penambahan fermentasi bahan baku lokal yang diberi amonium sulfat 1,5\% dan urea 1,5\% diperoleh hasil yang tidak nyata terhadap bobot hidup (1.552--1.717 g/ekor), bobot karkas (805,6--1.016 g/ekor), dan giblet (106,8--118,45 g/ekor) pada itik hibrida jantan.
\end{abstract}

Kata kunci: Bobot giblet, Bobot hidup, Bobot karkas, Itik hibrida jantan.

\section{PENDAHULUAN}

Saat ini kebutuhan masyarakat untuk mengkonsumsi daging itik guna mencukupi kebutuhan protein hewani meningkat. Daging itik banyak diminati, karena memiliki rasa yang relatif enak dan gurih. Seiring dengan meningkatnya permintaan pada daging itik, usaha peternakan itik pun semakin banyak diminati sebagai salah satu peluang usaha peternakan unggas yang menguntungkan. Itik lokal jantan merupakan salah satu ternak yang dimanfaatkan untuk menghasilkan daging.
Usaha peternakan itik, ransum merupakan faktor yang penting agar pertumbuhan dan produksi maksimal. Biaya ransum merupakan komponen pengeluaran yang terbesar pada usaha produksi itik. Oleh sebab itu, perlu upaya untuk menekan biaya ransum agar dapat meningkatkan keuntungan peternak dan membantu dalam pengembangan usaha pemeliharaan itik.

Penggunaan bahan pakan lokal merupakan upaya yang banyak dilakukan oleh peternak untuk menekan biaya ransum Bahan pakan lokal seperti bungkil kelapa sawit, onggok, dan dedak adalah bahan pakan lokal yang ketersediaannya 
melimpah dan selalu dikaitkan dengan harganya yang murah. Akan tetapi ada faktor pembatas dengan bahan baku lokal yaitu serat kasar yang tinggi. Proses pengolahan secara fermentasi dapat membantu mengatasi masalah tersebut, sehingga pemanfaatan bahan baku berbasis bahan baku lokal bisa dioptimalkan dalam ransum ternak itik (Murwani, 2010). Fermentasi merupakan suatu proses pengolahan bahan yang umumnya mengandung serat tinggi yang diuraikan menggunakan mikroorganisme seperti Effective Microorganism 4 (EM4). Proses fermentasi dengan menggunakan mikroba EM4 dapat meningkatkan nilai kecernaan dan menambah rasa dan aroma serta meningkatkan vitamin dan mineral bahan pakan (Murwani, 2010). EM4 merupakan dapat mendegradasi kandungan serat kasar (lignin), karena memiliki kemampuan untuk menghasilkan enzim laccases dan peroksidase yang dapat merombak dan melarutkan lignin yang terkandung pada bahan pakan yang berperan sebagai sumber energi bagi ternak. EM4 juga berperan meningkatkan kecernaan, sintesa protein, mengurangi bau kotoran, dan ramah lingkungan (Mangisah et al., 2009).

Hasil penelitian Septinova et al., (2017) menunjukkan bahan terfermentasi campuran bungkil kelapa sawit $80 \%$, dedak $10 \%$, dan onggok $10 \%$ belum memberikan hasil yang optimal terhadap kualitas nutrisi campuran bahan pakan dan performa itik hibrida jantan. Penambahan bahan anorganik seperti amonium sulfat dan urea perlu dilakukan untuk meningkatkan nilai nutrisi produk fermentasi bahan baku lokal tersebut. Berdasarkan hal tersebut maka perlu dilakukan penelitian mengenai penambahan ransum komersil dengan bahan pakan lokal terfermentasi amonium sulfat dan urea terhadap bobot hidup, bobot karkas karkas, dan giblet pada itik hubrida jantan.

\section{MATERI DAN METODE}

\section{Materi}

Itik yang digunakan pada penelitian ini adalah 40 ekor itik hibrida jantan berumur 4 minggu dengan bobot 1070,5 $\pm 76,36$ g/ekor. Ransum yang digunakan pada penelitian ini adalah ransum komersil Broiler 2 (BR2), dedak padi, bungkil sawit, onggok EM4, amonium sulfat dan urea berbentuk mash dengan kadar protein kasar $(17,5 \%)$.

\section{Metode}

Penelitian ini dilakukan secara eksperimental dengan menggunakan metode Rancangan Acak
Lengkap (RAL) terdiri atas 4 perlakuan 5 ulangan. Masing-masing ulangan terdiri atas 2 ekor itik. Adapun perlakuan yang digunakan yaitu :

R0: ransum komersil

R1: $80 \%$ ransum komersil $+20 \%$ BPF 1

R2: $80 \%$ ransum komersil $+20 \%$ BPF 2

R3: $80 \%$ ransum komersil $+20 \%$ BPF 3

Keterangan:

BPF1: Bahan pakan terfermentasi 1 menggunakan bahan pakan lokal $(80 \%$ bungkil kelapa sawit, $10 \%$ onggok, $10 \%$ dedak padi, 10\% EM4, 5\% molasses, $40 \%$ air dan $1,5 \%$ urea)

BPF 2: Bahan pakan terfermentasi 2 menggunakan bahan pakan lokal $(80 \%$ bungkil kelapa sawit, $10 \%$ onggok, $10 \%$ dedak padi, 10\% EM4, 5\% molasses, $40 \%$ air dan $1,5 \%$ amonium sulfat)

BPF 3: Bahan pakan terfermentasi 3 menggunakan bahan pakan lokal $(80 \%$ bungkil kelapa sawit, $10 \%$ onggok, $10 \%$ dedak padi, 10\% EM4, 5\% molasses, $40 \%$ air, $1,5 \%$ urea dan $1,5 \%$ amonium sulfat)

Ransum komersil : Ransum jadi dengan merk Broiler II (BR2) PT. Japfa Comfeed

\section{Analisis Data}

Data yang diperoleh dilakukan analisis analisis of varian (ANOVA). Apabila dari hasil analisis varian menunjukkan hasil yang nyata, maka dilanjutkan dengan uji Beda Nyata Terkecil (BNT) untuk mencari ransum terbaik.

\section{HASIL DAN PEMBAHASAN}

\section{Pengaruh Perlakuan Terhadap Bobot Hidup}

Rata-rata bobot hidup itik hibrida jantan selama penelitian berkisar antarara

1.552--1.717 g, dapat dilihat pada Tabel 1. Hasil analisis ragam menunjukkan bahwa pemberian ransum komersil dengan perbedaan bahan baku lokal terfermentasi amonium sulfat dan urea berpengaruh tidak nyata $(\mathrm{P}>0,05)$ terhadap bobot hidup (Tabel 1). Berdasarkan Tabel 1, dapat dilihat bahwa rerata bobot hidup tertinggi adalah $1.717 \mathrm{~g}$ terdapat pada R2 dan terendah adalah 1552 g pada perlakuan R3. Bobot hidup yang diperoleh dalam penelitian ini lebih tinggi dari hasil penelitian Matitaputty et al (2011), bobot hidup itik hibrida jantan umur 8 minggu adalah $1.340--1436 \mathrm{~g}$. 
Tabel 1. Rata-rata bobot hidup (g) itik hibrida jantan percobaan umur 8 minggu

\begin{tabular}{ccccc}
\hline \multirow{2}{*}{ Ulangan } & \multicolumn{5}{c}{ Perlakuan } \\
\cline { 2 - 5 } & R0 & R1 & R2 & R3 \\
\cline { 2 - 5 } & -------------------g----------------- \\
1 & 1.425 & 1.630 & 1.645 & 1.455 \\
2 & 1.905 & 1.783 & 1.660 & 1.645 \\
3 & 1.525 & 1.625 & 1.730 & 1.685 \\
4 & 1.635 & 1.575 & 2.055 & 1.375 \\
5 & 1.750 & 1.500 & 1.495 & 1.600 \\
\hline \multirow{2}{*}{ Rata-rata } & $1.648 \pm$ & $1.622, \pm$ & $1.717 \pm$ & $1.552 \pm$ \\
& 188,07 & 103,78 & 207,44 & 131,70 \\
\hline
\end{tabular}

Keterangan:

R0: ransum komersil

R1: $80 \%$ ransum komersil $+20 \%$ BPF 1

R2: $80 \%$ ransum komersil $+20 \%$ BPF 2

R3: $80 \%$ ransum komersil $+20 \%$ BPF 3

Deaton dan Lott (1985) menyatakan bahwa bobot hidup dipengaruhi oleh konsumsi ransum, kandungan energi, dan protein kasar di dalam ransum. Semakin banyak konsumsi ransum yang diikuti dengan daya cerna yang baik, maka akan semakin banyak nutrisi yang diserap dan digunakan untuk pertumbuhan. Hal tersebut dapat berdampak terhadap bobot hidup yang semakin tinggi.

Pemberian amonium sulfat urea pada taraf $1,5 \%$ dalam ransum itik umur 2--8 minggu memiliki potensi paling baik untuk meningkatkan kandungan protein kasar ransum, penambahan amonium sulfat $1,5 \%+$ urea $1,5 \%$ mampu meningkatkan kandungan protein ransum bahan baku lokal dari $8,11 \%$ menjadi $16,72 \%$. Hal ini menunjukkan bahwa bahan baku lokal terfermentasi amonium sulfat $1,5 \%+$ urea $1,5 \%$ dapat dijadikan solusi untuk digunakan dalam ransum itik guna meningkatkan bobot hidup dan mengurangi biaya produksi dengan mengurangi penggunaan pakan komersil. Namun, pemberian bahan pakan fermentasi tersebut sebanyak $20 \%$ dalam ransum komersil tidak menyebabkan perbedaan yang mencolok pada kandungan nutrisi protein kasar, lemak kasar, dan serat kasar ransum pada R1, R2, dan R3 sehingga konsumsi ransum relatif sama dan akhirnya bobot hidup itik relatif tidak berbeda.

Jika dilihat dari penelitian ini pemberian bahan baku lokal terfermentasi amonium sulfat dan urea dalam ransum dengan protein dan energi metabolis yang relatif sama menghasilkan bobot potong dan bobot karkas yang relatif sama. Pemberian protein $17,5 \%$ pada penelitian ini dinilai memiliki potensi yang sama antara perlakuan satu dengan yang lain. Oleh karena itu untuk menghasilkan data penelitian yang lebih baik maka perlu penambahan kadar protein ransum. Hal ini sesuai pendapat Ramina (2001) menyatakan bahwa dengan meningkatkan kandungan protein dalam ransum secara nyata dapat meningkatkan bobot karkas dan bobot hidup. Hal ini dapat terjadi karena asupan protein dan asam amino pada ransum kurang tercukupi di dalam tubuh itik sehingga metabolisme sel tubuh berjalan kurang optimal sehingga peningkatan bobot karkas dan bobot hidup kurang maksimal.

Konsumsi ransum juga dipengaruhi oleh palatabilitas ransum. Pemberian pakan berbasis bahan baku lokal yang difermentasi menggunakan amonium sulfat dan urea dalam ransum menjadikan warna dan aroma khas pada ransum. Warna pada ransum menjadi cokelat pada perlakuan R1, R2, dan R3, disebabkan oleh fermentasi yang dilakukan. Hasil penelitian ini menunjukkan bahwa warna pada ransum tidak mempengaruhi konsumsi ransum itik hibrida jantan. Dampak dari konsumsi relatif sama pada R0, R1, R2, dan R3 menyebabkan bobot hidup relatif sama. Hal ini sesuai dengan pendapat Murtidjo (2003) yang menyatakan bahwa bobot hidup erat kaitannya dengan konsumsi ransum, dengan meningkatnya konsumsi ransum maka bobot hidup yang didapat semakin meningkat, demikian pula sebaliknya.

\section{Pengaruh Perlakuan terhadap Bobot Karkas}

Karkas adalah bagian tubuh yang sudah melalui proses penyembelihan secara halal, pencabutan bulu, pengeluaran jerohan, tanpa kepala, dan ceker. Rata-rata bobot karkas dari itik jantan lokal yang diberikan ransum dengan penambahan bahan baku lokal terfermentasi amonium sulfat $1,5 \%$ dan urea 1,5\%dapat dilihat pada Tabel 2 .

Berdasarkan hasil analisis ragam (Tabel 2) pemberian ransum dengan penambahan bahan baku lokal terfermentasi urea $1,5 \%$ dan ammonium sulfat $1,5 \%$ dalam ransum berpengaruh tidak nyata $(\mathrm{P}>0,05)$ terhadap bobot karkas. Hal ini menunjukkan bahwa seluruh kandungan nutrisi pada semua perlakuan dialokasikan relatif sama terhadap bobot karkas.

Ransum yang baik adalah ransum yang memiliki nutrisi yang sesuai dengan kebutuhan ternak. Protein adalah salah satu unsur utama dalam ransum untuk memenuhi kebutuhan pertumbuhan dan produksi bagi ternak. Kandungan protein yang tidak sesuai dengan kebutuhan akan menghambat pertumbuhan, dalam penelitian ini ransum dengan campuran bahan pakan terfermentasi amonium sulfat 1,5\% dan urea $1,5 \%$ mengandung protein kasar sebesar 
17,5\%. Berdasarakan tabel kebutuhan SNI (2006) protein kasar dan energi metabolis itik jantan umur 4--8 minggu adalah 18--22\% dan untuk energi metabolis adalah 2900--3000 kkal.

Tabel 2. Rata-rata bobot karkas itik hibrida jantan percobaan umur 8 minggu

\begin{tabular}{ccccc}
\hline \multirow{2}{*}{ Ulangan } & \multicolumn{4}{c}{ Perlakuan } \\
\cline { 2 - 5 } & R0 & R1 & R2 & R3 \\
\cline { 2 - 5 } 1 & & & & \\
2 & 833 & 930 & 940 & 876 \\
2 & 1.094 & 984 & 969 & 803 \\
3 & 831 & 910 & 1.027 & 864 \\
4 & 1.028 & 828 & 1.187 & 952 \\
5 & 948 & 874 & 957 & 933 \\
\hline \multirow{2}{*}{ Rata-rata } & $946,8 \pm$ & $905,2 \pm$ & $1.016 \pm$ & $885,6 \pm$ \\
& 116,86 & 58,70 & 101,03 & 59,24 \\
\hline
\end{tabular}

Keterangan:

R0: ransum komersil

R1: $80 \%$ ransum komersil $+20 \%$ BPF 1

R2: $80 \%$ ransum komersil $+20 \%$ BPF 2

$\mathrm{R} 3: 80 \%$ ransum komersil $+20 \% \mathrm{BPF} 3$

Protein dalam pakan sangat penting untuk bobot karkas karena di dalam protein mengandung asam amino yang penting bagi pertumbuhan seperti valin unuk membantu dalam pertumbuhan otot dan leusin yang meningkatkan sintesis hormon pertumbuhan. Namun, pemberian protein dalam ransum tidak boleh lebih dari kebutuhan ternak karena protein hanya akan terbuang lewat menur pada unggas dan tidak digunakan untuk pertumbuhan maupun produksi.

Bobot karkas berkaitan dengan bobot potong, semakin tinggi bobot potong maka bobot karkasnya tinggi dan semakin rendah bobot potong maka bobot karkas juga rendah. Bobot karkas dapat dipengauhi oleh nutrisi ransum yang diberikan, salah satu nutrisi yang berperan dalam bobot karkas pada ransum yaitu protein. Protein dalam pakan yang dikonsumsi akan dipecah dan dirombak di bagian proventikulus dan usus menjadi asam amino (Wahju, 1992). Asam amino akan digunakan untuk pembentukan jaringan otot (NRC, 1994). Otot merupakan sumber daging yang utama, sehingga akan berpengaruh dominan pada dada, paha dan sayap yang kemudian berpengaruh terhadap bobot karkas (Yuwanta, 2004).

\section{Pengaruh Perlakuan Terhadap Bobot Giblet}

Rata-rata bobot giblet itik jantan lokal selama penelitian berkisar antara 106,8--118,45 g/ekor (Tabel 3). Hasil analisis ragam menunjukkan bahwa pemberian ransum dengan penambahan bahan baku lokal terfermentasi urea $1,5 \%$, amonium sulfat $1,5 \%$ dan amonium sulfat $1,5 \%$ + urea $1,5 \%$ berpengaruh tidak nyata $(\mathrm{P}>0,05)$ terhadap bobot giblet (Tabel 3).

Tabel 3. Rata-rata bobot giblet itik jantan lokal percobaan umur 8 minggu

\begin{tabular}{crccc}
\hline \multirow{2}{*}{ Ulangan } & \multicolumn{5}{c}{ Perlakuan } \\
\cline { 2 - 5 } & R0 & R1 & R2 & R3 \\
\hline & & & & \\
1 & 120 & 118 & 112 & 110 \\
2 & 134 & 135 & 113 & 108 \\
3 & 108 & 109 & 115 & 97 \\
4 & 129 & 141 & 141 & 113 \\
5 & 130 & 118 & 112 & 106 \\
\hline \multirow{2}{*}{ Rata-rata } & 118,45 & $\begin{array}{c}116,5333 \\
\pm 10,40\end{array}$ & $\begin{array}{c}113,29 \\
\pm 12,28\end{array}$ & $\begin{array}{c}106, \\
\pm 6,06\end{array}$ \\
\hline Keterangan & & &
\end{tabular}

Keterangan:

R0: ransum komersil

R1: $80 \%$ ransum komersil $+20 \%$ BPF 1

R2: $80 \%$ ransum komersil $+20 \%$ BPF 2

R3: $80 \%$ ransum komersil $+20 \%$ BPF 3

Hasil penelitian ini menunjukkan bahwa itik memiliki bobot hidup yang relatif sama, sehingga bobot giblet relatif sama antar perlakuan. Bobot giblet sangat dipengaruhi oleh bobot hidup itik. Soeparno (2005), bobot hidup mempengaruhi bobot giblet, semakin besar bobot hidup maka bobot giblet yang dihasilkan akan meningkat. Itik yang memiliki bobot hidup yang tinggi akan memiliki bobot giblet yang tinggi sedangkan itik yang memiliki bobot hidup rendah memiliki bobot giblet yang rendah.

Dharmawati dan Ari (2012), meningkatnya bobot giblet bukan disebabkan oleh meningkatnya pertumbuhan, melainkan karena fungsinya yang cukup berat dalam mencerna bahan makanan menjadi partikel yang lebih kecil, juga untuk mengaduk bahan tersebut dengan enzim pencernaan yang dihasilkan proventikulus maupun empedu, sehingga pembesaran giblet ini sangat dipengaruhi oleh kuantitas dan sifat serat kasar bahan pakan. Hasil penelitian menunjukkan bahwa kandungan serat kasar pada kontrol (R0) adalah 4,07\%, sedangkan serat kasar pada perlakuan yang menggunakan bahan baku lokal terfermentasi lebih tinggi yaitu 7,62\% (R1), 10,00\% (R2), dan $8,51 \%$ (R3). Namun, kandungan serat kasar yang tinggi tidak berpengaruh terhadap bobot 
giblet itik. Artinya, pemberian pakan lokal terfermentasi masih aman diberikan sampai dengan tingkat $10 \%$ sebagai pengganti ransum komersil. Hal ini karena kandungan serat kasar ransum perlakuan yang mengandung bahan pakan lokal masih dalam batas toleransi. Batas toleransi serat kasar untuk itik adalah sebesar 7-10\% (SNI,2006).

Bobot gizzard dari keempat perlakuan menghasilkan rataan sebesar 68,4 g dapat dilihat pada (Tabel 4). Hasil analisis ragam menunjukkan bahwa pemberian ransum dengan penambahan baku lokal terfermentasi urea dan ammonium sulfat $1.5 \%$ berpengaruh tidak nyata $(\mathrm{P}>0,05)$ terhadap bobot gizzard. Dharmawati dan Ari (2012) menyatakan bobot gizzard dipengaruhi oleh umur, bobot badan, dan pakan. Bobot hidup yang tidak berbeda nyata menyebabkan bobot gizzard tidak berbeda nyata.

Tabel 4. Rata-rata bobot gizzard itik jantan lokal umur 58 hari

\begin{tabular}{crrrr}
\hline \multirow{2}{*}{ Ulangan } & \multicolumn{4}{c}{ Perlakuan } \\
\cline { 2 - 5 } & $\mathrm{R} 0$ & $\mathrm{R} 1$ & $\mathrm{R} 2$ & $\mathrm{R} 3$ \\
\hline 1 & 68 & 68 & 62 & 62 \\
2 & 81 & 80 & 63 & 61 \\
3 & 62 & 61 & 71 & 50 \\
4 & 70 & 84 & 83 & 63 \\
5 & 83 & 71 & 65 & 60 \\
\hline Jumlah & 364 & 364 & 344 & 296 \\
Rata-rata & 72,8 & 72,8 & 68,8 & 59,2 \\
\hline Keterangan & & & &
\end{tabular}

Keterangan:

R0: ransum komersil

$\mathrm{R} 1: 80 \%$ ransum komersil $+20 \% \mathrm{BPF} 1$

R2: $80 \%$ ransum komersil $+20 \%$ BPF 2

R3: $80 \%$ ransum komersil $+20 \%$ BPF 3

Bobot hati dari keempat perlakuan menghasilkan rataan sebesar 38,25 g (Tabel 5). Hasil analisis ragam menunjukkan bahwa pemberian ransum dengan penambahan bahan baku lokal terfermentasi amonium sulfat dan urea 1,5\% berpengaruh tidak nyata $(\mathrm{P}>0,05)$ terhadap bobot hati. Rasyaf (2001) menyatakan bahwa fungsi hati yang utama adalah membantu metabolisme dalam tubuh yang prosesnya tidak terelepas dari kandungan nutrisi yang diberikan. Asupan nutrisi pakan penelitian yang kandungan serat kasar, protein dan energi metabolis yang hampir sama menyebabkan keadaan metabolisme yang terjadi di dalam tubuh ternak juga sama akibat nutrisi pakan tersebut.
Tabel 5. Rata-rata bobot hati itik jantan lokal umur 58 hari

\begin{tabular}{ccccc}
\hline \multirow{2}{*}{ Ulangan } & \multicolumn{4}{c}{ Perlakuan } \\
\cline { 2 - 5 } & $\mathrm{R} 0$ & $\mathrm{R} 1$ & $\mathrm{R} 2$ & $\mathrm{R} 3$ \\
\hline 1 & 41 & 39 & 40 & 36 \\
2 & 41 & 43 & 38 & 35 \\
3 & 37 & 32 & 34 & 37 \\
4 & 47 & 43 & 43 & 36 \\
5 & 35 & 36 & 36 & 36 \\
\hline Jumlah & 201 & 193 & 191 & 180 \\
Rata-rata & 40,2 & 38,6 & 38,2 & 36 \\
\hline Keterangan & & & &
\end{tabular}

Keterangan:

R0: ransum komersil

R1: $80 \%$ ransum komersil $+20 \%$ BPF 1

R2: $80 \%$ ransum komersil $+20 \%$ BPF 2

R3: $80 \%$ ransum komersil $+20 \%$ BPF 3

Bobot jantung dari keempat perlakuan menghasilkan rataan sebesar 11,8 g (Tabel 6). Hasil analisis ragam menunjukkan bahwa pemberian ransum dengan penambahan baku lokal terfermentasi amonium sulfat dan urea $1,5 \%$ berpengaruh tidak nyata $(\mathrm{P}>0,05)$ terhadap bobot jantung. Ressang (1984) menyatakan bahwa besar jantung tergantung dari jenis kelamin, umur, bobot hidup dan aktivitas hewan. Kandang yang digunakan pada penelitian ini adalah kandang postal ukuran $0,8 \times 0,6 \mathrm{~m}$ untuk dua ekor itik sehingga aktivitas itik tidak terlalu banyak bergerak. Aktivitas itik pada sistem pemeliharaan terkurung memungkinkan kerja jantung dalam memompa darah tidak terlalu berat, karena tidak banyak melakukan aktivitas.

Tabel 6. Rata-rata bobot jantung itik jantan lokal umur 58 hari

\begin{tabular}{ccccc}
\hline \multirow{2}{*}{ Ulangan } & \multicolumn{3}{c}{ Perlakuan } & \\
\cline { 2 - 5 } & $\mathrm{R} 0$ & $\mathrm{R} 1$ & $\mathrm{R} 2$ & $\mathrm{R} 3$ \\
\hline 1 & 11 & 11 & 10 & 12 \\
2 & 12 & 12 & 12 & 12 \\
3 & 9 & 16 & 10 & 10 \\
4 & 12 & 14 & 15 & 14 \\
5 & 12 & 11 & 11 & 10 \\
\hline \multirow{2}{*}{ Jumlah } & 56 & 64 & 58 & 58 \\
Rata-rata & 11,2 & 12,8 & 11,6 & 11,6 \\
\hline
\end{tabular}

Keterangan:

R0: ransum komersil

$\mathrm{R} 1: 80 \%$ ransum komersil $+20 \%$ BPF 1

R2: $80 \%$ ransum komersil $+20 \%$ BPF 2

R3: $80 \%$ ransum komersil $+20 \%$ BPF 3 


\section{KESIMPULAN}

Berdasarkan hasil penelitian dapat disimpulkan bahwa pemberian ransum dengan penambahan fermentasi bahan baku lokal yang diberi amonium sulfat $1,5 \%$ dan urea $1,5 \%$ berpengaruh tidak nyata terhadap bobot hidup (1.552--1.717 g/ekor), bobot giblet (106,8--118,45 g/ekor ), dan bobot karkas (805,6--1.016 g/ekor) itik hibrida jantan.

\section{DAFTAR PUSTAKA}

Deaton, J.W. and B.D. Lott. 1985. Age and Dietary Energy Effect On Broiler Abdominal Fat Deposition. Poult Sci. 64: 2161--2164

Dharmawati, S dan Ari J. K. 2012. Pengaruh Penggunaan Tepung Daun Alang-Alang (Imprata cylindricaII) dalam Ransum terhadap Kadar Lemak,Kolesterol Karkas dan Organ Pencernaan Itik Alabio Jantan. Ziaraa'h Volume 34 No.2:150--160

Mangisah, I. N. Suthana dan H. I. Wahyuni. 2009. Pengaruh Penambahan Starbio dalam Ransum Berserat Kasar Tinggi terhadap Performans Itik. Proseding Seminar Nasional Kebangkitan Peternakan. Semarang, 20 Mei 2009. Undip. Semarang. Pp.688--694

Murtidjo, B.A. 2003. Pedoman Meramu Pakan Unggas. Kanisius. Yogyakarta

Murwani, R. 2010. Rekayasa Nutrisi Berbahan Pakan Lokal untuk Meningkatkan Imunitas dan Produktivitas Unggas. Laporan Hibah Kompetitif, Universitas Diponegoro. Semarang

NRC. 1994. Nutrient requirements of poultry. National Academy Press. Washington

Rasyaf, M. 2001. Bahan Makanan Unggas di Indonesia. Cetakan ke-9 Penerbit Kanisius. Yogyakarta

Ressang, A.A. 1984. Patologi Khusus Veteriner. Edisi II. N. V. Percetakan Bali. Denpasar

SNI 01-3909-2006 Pakan Itik. 2006. https://forsum.wordpress.com/dasar forsum/nutrient/standar nasional indonesia-sni-pakan. Diakses pada hari Kamis 09 November 2018

Septinova, D., C. Aji Tama, dan Tintin Kurtini. 2017. Pengaruh pemberian jamu tradisional terhadap bobot hidup, bobot karkas, bobot giblet, dan lemak abdominal broiler. Jurnal Penelitian Peternakan Inodonesia 1(2): 16-21
Soeparno. 2005. Ilmu dan Teknologi Daging. Edisi ke-3. Gadjah Mada University Press. Yogyakarta

Wahju, J. 1992. Ilmu Nutrisi Unggas. Gadjah Mada University Press. Yogyakarta

Yuwanta, T. 2004. Dasar Ternak Unggas. Kanisuis. Yogyakarta 